\title{
Confirmatory Factor Analysis (CFA) For the Instrument of Personality, Safety Climate and Safety Performance in The Malaysia Manufacturing Sector
}

Nurul Hidayu Mat Jusoh, Siti Aisyah Panatik, Mohd Ibrani Shahrimin Adam Assim, Yasmin Yaacob \& Nurul Nadwa Zulikifli

To Link this Article: http://dx.doi.org/10.6007/IJARBSS/v11-i17/11349

DOI:10.6007/IJARBSS/v11-i17/11349

Received: 02 August 2021, Revised: 01 September 2021, Accepted: 29 September 2021

Published Online: 10 October 2021

In-Text Citation: (Jusoh et al., 2021)

To Cite this Article: Jusoh, N. H. M., Panatik, S. A., Assim, M. I. S. A., Yaacob, Y., \& Zulikifli, N. N. (2021).

Confirmatory Factor Analysis (CFA) For the Instrument of Personality, Safety Climate and Safety Performance in The Malaysia Manufacturing Sector. International Journal of Academic Research in Business and Social Sciences, 11(17), 1-16.

Copyright: (C) 2021 The Author(s)

Published by Human Resource Management Academic Research Society (www.hrmars.com) This article is published under the Creative Commons Attribution (CC BY 4.0) license. Anyone may reproduce, distribute, translate and create derivative works of this article (for both commercial and non-commercial purposes), subject to full attribution to the original publication and authors. The full terms of this license may be seen

at: http://creativecommons.org/licences/by/4.0/legalcode

Special Issue Title: Empowering Community and Beyond, iRandau, 2021, Pg. 1 - 16

Full Terms \& Conditions of access and use can be found at http://hrmars.com/index.php/pages/detail/publication-ethics 


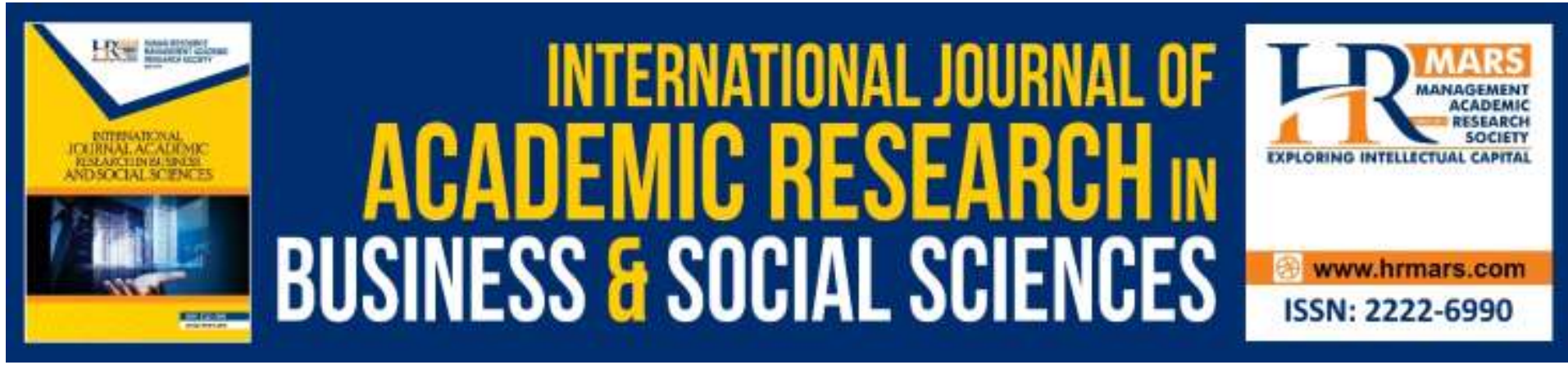

\title{
Confirmatory Factor Analysis (CFA) For the Instrument of Personality, Safety Climate and Safety Performance in The Malaysia Manufacturing Sector
}

Nurul Hidayu Mat Jusoh ${ }^{1}$, Siti Aisyah Panatik², Mohd Ibrani Shahrimin Adam Assim ${ }^{3}$, Yasmin Yaacob ${ }^{4}$ \& Nurul Nadwa Zulikifli ${ }^{5}$

${ }^{1,3,4}$ Department of Social Science and Management Faculty of Humanities, Management and Science, Universiti Putra Malaysia (Bintulu Campus), Bintulu, Sarawak, Malaysia,

${ }^{2}$ School of Human Resources Development \& Psychology, Faculty of Social Sciences and Humanities, Universiti Teknologi Malaysia, Johor Bahru, Johor, Malaysia, ${ }^{5}$ Department of Science and Engineering, Faculty of Humanities, Management and Science, Universiti Putra Malaysia (Bintulu Campus), Bintulu, Sarawak, Malaysia.

Email: nurulhidayu@upm.edu.my

\begin{abstract}
This paper aims to draw on the application of Confirmatory Factor Analysis (CFA) in Structural Equation Modeling (SEM), to test the validity and reliability of instruments in the study of personality, safety climate, and safety performance in the Malaysia manufacturing sector. Exploratory factor analysis (EFA) was employed to determine the best sub-factors and items for the instrument, while confirmatory factor analysis (CFA) was performed to test and validate the measurement model. Confirmatory Factor Analysis (CFA) using Structural Equation Modeling (SEM) Partial Least Square (PLS), has been used to test the validity and reliability of the instruments. Various tests i.e., construct validity analysis, construct reliability, validity convergent as well as discriminatory validity to filter the best items that can represent the constructs in the study. Results from CFA indicated that two items from the Safety Performance Scale (SPS) had to be discarded to confirm that the model was fit. Meanwhile, all items from the Safety Climate Scale (SCS) and Mini-International Personality Item Pool (IPIP) were maintained. Overall, the final version of the instrument consisted of Safety Climate Instruments (46 items), Big Five Personality Instruments (20 items), and Safety Performance Instruments ( 37 out of 39 items).
\end{abstract}

Keywords: Confirmatory Factor Analysis, Structural Equation Modeling, Personality Big Five, Safety Climate, Safety Performance. 


\section{Introduction}

Research instruments refer to the tools used by researchers to collect data. For quantitative data, the questionnaire is usually used as an instrument to collect data as in this study. To measure the personality among employees of production operators in the manufacturing sector (electrical and electronics) the researcher used a questionnaire Mini-International Personality Item Pool (IPIP) by Donnellan et al (2006). This Mini-IPIP questionnaire comes from a 50-item questionnaire International Personality Item Pool Five-Factor Model (IPIPBF) by Goldberg (1999) which was later shortened to 20 items (Baldasaro et al., 2013). Next, the safety climate in this study was measured using the Safety Climate Scale (SCS) by Wu et al (2007). This instrument has 46 questions and consists of five dimensions namely CEO safety commitment and action, manager safety commitment, employee safety commitment, perceived risk, and emergency response. Safety performance is measured using the Safety Performance Scale (SPS) by (Wu et al., 2008). This scale has 39 items with six dimensions namely safety organization and management, safety equipment and measures, safety training practices, safety training evaluation, accident investigation, and accident statistics.

\section{Methodology}

In this study, the researcher has tested the measurement model on the study instrument through SEM PLS (Partial Least Square) analysis, using SmartPLS software version 3. Analysis of the measurement model on this study instrument was conducted by performing construct validity analysis, construct reliability, convergent validity as well as discriminatory validity to filter the best items that can represent the constructs in the study.

\section{Construct Validity Analysis}

To analyse the validity of the construct, the researcher has used the factor loading to test whether all items are loaded to the appropriate factors or not. According to Greeno et al., (2007) there are various suggestions to assess the acceptable level of factor loading based on the literature. For this study, the researcher set the factor loading value for each item that must exceed the value of 0.50 as suggested by (Hair et al., 1998). According to Hair, et al (1998) sample size of more than 120 is practical to use cut-off loading factor $>0.50$. Therefore, researchers have adopted this criterion in testing the results of factors loading. The validity analysis of the construct based on the factor loading for each study variable is as follows.

\section{Construct Validity Analysis for Safety Climate Instruments}

In this study, safety climate variables are measured using Safety Climate Scale (SCS) by Wu et al., (2007) through five dimensions namely CEO safety commitments and actions, manager safety commitments, employee safety commitments, perceived risk, and emergency response. Researchers have tested the factor loading for each item in the five dimensions. The results of the analysis found that all items in the five dimensions of safety climate have been loaded to factors that match the value of the acceptable factor loading which is between 0.76-0.89 for the dimensions of CEO safety commitment and action, 0.79-0.89 for the dimensions of manager safety commitment, $0.79-0.89$ for the employee safety commitment, $0.72-0.90$ for the perceived risk dimension and 0.71-0.84 for the emergency response dimension. Table 1 below shows the factor loading values for all dimensions in the safety climate above the value of 0.50 . Therefore, the researcher chose to retain all items in the safety climate dimension for further analysis. 
Table 1: Factor loading for safety climate dimensions

\begin{tabular}{|c|c|c|}
\hline Dimensions & Item & $\begin{array}{l}\text { Factor } \\
\text { Loading } \\
(>0.50)\end{array}$ \\
\hline \multirow{10}{*}{$\begin{array}{l}\text { CEO } \\
\text { safety commitment } \\
\text { and action }\end{array}$} & The CEO provides a safe work environment & 0.83 \\
\hline & $\begin{array}{l}\text { The CEO allocates resources (such as money and } \\
\text { equipment) to improve workplace safety facilities }\end{array}$ & 0.83 \\
\hline & The CEO appoints a full-time safety manager & 0.76 \\
\hline & $\begin{array}{l}\text { The CEO states that safety and instructions } \\
\text { compliance is equally important }\end{array}$ & 0.79 \\
\hline & $\begin{array}{l}\text { The CEO is always informed of workplace safety } \\
\text { policies }\end{array}$ & 0.79 \\
\hline & $\begin{array}{l}\text { The CEO is always involved in the workplace safety } \\
\text { committee }\end{array}$ & 0.82 \\
\hline & The CEO pays more attention to employee safety & 0.86 \\
\hline & $\begin{array}{l}\text { The CEO always visits the work environment and } \\
\text { understands the safe environment }\end{array}$ & 0.89 \\
\hline & $\begin{array}{l}\text { The CEO regularly reviews safety and health } \\
\text { management in the workplace }\end{array}$ & 0.88 \\
\hline & $\begin{array}{l}\text { The CEO is constantly reviewing safety management } \\
\text { practices }\end{array}$ & 0.85 \\
\hline \multirow{11}{*}{$\begin{array}{l}\text { Manager safety } \\
\text { commitment }\end{array}$} & My manager provides adequate safety facilities & 0.84 \\
\hline & $\begin{array}{l}\text { My manager made observations on the safety } \\
\text { facilities provided }\end{array}$ & 0.89 \\
\hline & $\begin{array}{l}\text { My manager stated the importance of safety training } \\
\text { in my work }\end{array}$ & 0.83 \\
\hline & $\begin{array}{l}\text { My manager states that safety and compliance are } \\
\text { equally important }\end{array}$ & 0.80 \\
\hline & $\begin{array}{l}\text { My manager pays more attention to employee } \\
\text { welfare }\end{array}$ & 0.82 \\
\hline & $\begin{array}{l}\text { My manager always praises employees who behave } \\
\text { safely }\end{array}$ & 0.83 \\
\hline & $\begin{array}{l}\text { My manager allows employees to be involved in the } \\
\text { formation of workplace safety goals }\end{array}$ & 0.88 \\
\hline & $\begin{array}{l}\text { My manager is always discussing safety issues to his } \\
\text { employees }\end{array}$ & 0.82 \\
\hline & $\begin{array}{l}\text { My managers always provide workplace safety } \\
\text { information to employees }\end{array}$ & 0.79 \\
\hline & $\begin{array}{l}\text { My manager always practices the safety } \\
\text { recommendations provided by the employees }\end{array}$ & 0.80 \\
\hline & I am willing to undergo a physical safety check & 0.86 \\
\hline \multirow{4}{*}{$\begin{array}{l}\text { Employee safety } \\
\text { commitment }\end{array}$} & I am willing to engage in safety training & 0.89 \\
\hline & I am willing to abide by safety rules & 0.88 \\
\hline & I am willing to improve safety at work & 0.82 \\
\hline & $\begin{array}{l}\text { I am willing to give suggestions for improvement of } \\
\text { safety }\end{array}$ & 0.86 \\
\hline
\end{tabular}




\begin{tabular}{|c|c|c|}
\hline & I am willing to practice safety checks on my own & 0.79 \\
\hline & $\begin{array}{l}\text { I am willing to wear Personal Protection Equipment } \\
\text { (PPE) }\end{array}$ & 0.83 \\
\hline & $\begin{array}{l}\text { I am willing to practice the standard Safety Operating } \\
\text { Procedure (SOP) }\end{array}$ & 0.89 \\
\hline & $\begin{array}{l}\text { I am ready to keep the work environment clean and } \\
\text { organized }\end{array}$ & 0.88 \\
\hline & $\begin{array}{l}\text { I am willing to maintain the function of the safety } \\
\text { facilities available at work }\end{array}$ & 0.89 \\
\hline \multirow[t]{9}{*}{ Perceived risk } & While working I will not fall & 0.82 \\
\hline & While working I will not be electrocuted & 0.89 \\
\hline & While working I will not be stuck by the machine & 0.88 \\
\hline & $\begin{array}{l}\text { While working I will not be exposed to the extreme } \\
\text { heat of the work environment }\end{array}$ & 0.84 \\
\hline & $\begin{array}{l}\text { While working I will not be touched by harmful } \\
\text { substances }\end{array}$ & 0.90 \\
\hline & $\begin{array}{l}\text { While working I will not be exposed to infectious } \\
\text { substances (such as bacteria and viruses) }\end{array}$ & 0.89 \\
\hline & While working I will not lift things that are too heavy & 0.82 \\
\hline & $\begin{array}{l}\text { While working I could not withstand extreme work } \\
\text { stress }\end{array}$ & 0.72 \\
\hline & $\begin{array}{l}\text { While working I will not experience any physical } \\
\text { disorders }\end{array}$ & 0.84 \\
\hline \multirow[t]{7}{*}{ Emergency response } & $\begin{array}{l}\text { I know where the personal protective equipment } \\
\text { (PPE) is located }\end{array}$ & 0.80 \\
\hline & $\begin{array}{l}\text { I know the position of the emergency switch to stop a } \\
\text { machine }\end{array}$ & 0.83 \\
\hline & I know where the fire extinguisher is placed & 0.80 \\
\hline & I know where the first aid facility is located & 0.82 \\
\hline & I know the emergency route clearly & 0.71 \\
\hline & $\begin{array}{l}\text { I know the procedure that needs to be done to deal } \\
\text { with the problem of electric shock }\end{array}$ & 0.83 \\
\hline & I know the procedure to take in the event of a fire & 0.84 \\
\hline
\end{tabular}

\section{Construct Validity Analysis for big Five Personality Instruments}

Personality in this study was measure using the questionnaire Mini-International Personality Item Pool (IPIP) by Donnellan et al., (2006). The Mini-IPIP is divided into five traits namely openness to experience, conscientiousness, extrovertness, agreeableness, and neurotics. The researcher performed the factor loading analysis on the five personality traits as shown in Table 2. The results of the analysis found that all items in the five personality traits have a factor loading value exceeding 0.50 . The factor loading values between $0.80-0.87$ for openness to experience, $0.79-0.85$ for conscientiousness, $0.75-0.84$ for extrovertness, $0.75-$ 0.86 for agreeableness, and $0.79-0.84$ for neurotics. Therefore, all items in the personality trait have good construct validity for further analysis. 
Table 2: Factor loading for Big Five Personality dimensions

\begin{tabular}{|c|c|c|}
\hline Dimensions & Item & $\begin{array}{l}\text { Factor } \\
\text { Loading } \\
(>0.50)\end{array}$ \\
\hline \multirow{4}{*}{$\begin{array}{l}\text { Openness to } \\
\text { experience }\end{array}$} & I have a clear imagination & 0.85 \\
\hline & I am interested in abstract ideas & 0.86 \\
\hline & I like to understand abstract ideas & 0.87 \\
\hline & I have a good imagination & 0.80 \\
\hline \multirow[t]{4}{*}{ Conscientiousness } & I do my job well & 0.82 \\
\hline & I like to follow instructions & 0.79 \\
\hline & $\begin{array}{l}\text { I always put the things back to their original } \\
\text { place }\end{array}$ & 0.85 \\
\hline & I do the job as soon as possible & 0.83 \\
\hline \multirow[t]{4}{*}{ Extrovertness } & I am the main pillar of this factory & 0.81 \\
\hline & I like to talk a lot & 0.75 \\
\hline & $\begin{array}{l}\text { I like to get to know various groups in a } \\
\text { ceremony }\end{array}$ & 0.84 \\
\hline & I like to appear my self & 0.84 \\
\hline \multirow[t]{4}{*}{ Agreeableness } & I sympathize with the feelings of others & 0.75 \\
\hline & I am interested in other people's problems & 0.81 \\
\hline & I feel other people's emotions & 0.86 \\
\hline & I am interested in others & 0.75 \\
\hline \multirow[t]{4}{*}{ Neurotics } & I have frequent emotional changes & 0.79 \\
\hline & I do not relax most of the time & 0.81 \\
\hline & I am easily offended & 0.84 \\
\hline & I often feel depressed & 0.84 \\
\hline
\end{tabular}

\section{Construct Validity Analysis for Safety Performance Instruments}

Safety performance in this study was measure using the Safety Performance Scale (SPS) by $\mathrm{Wu}$ et al (2008). Table 3 shows the factors loading for the safety organization and management dimensions of safety between $0.18-0.69$, safety equipment and measures between $0.47-0.85$, safety training practices between $0.86-0.91$, safety training evaluation between $0.85-0.93$, accident investigation between $0.88-0.93$ and accident statistics between $0.83-0.92$. Researchers found that the factor loading value for all items exceeded the value of 0.50 except for two items, namely the item is from the safety organization and management dimension that is "my management states in writing their safety policy" and the item from the dimensions of safety equipment and measures that are "the pathway is always neat and orderly" which shows the factor loading values of 0.18 and 0.47 respectively. The value of factor loading less than 0.50 indicates a weak construct validity. This is in line with the recommendations by Hair et al (1998); Kline (2015), the value of factor loading must be $>0.50$. Therefore, researchers have decided to remove these two items for further analysis. The factor loading value for safety performance after removing these two items is 0.53 to 0.93 . The factor loading value of $0.53-0.93$ proves that the items in safety performance exceed the factor loading conditions proposed by Hair et al (1998); Kline (2015), and can be used for further analysis. 
Table 3: Factor loading for safety performance

\begin{tabular}{|c|c|c|}
\hline Dimensions & Item & $\begin{array}{l}\text { Factor Loading } \\
(>0.50)\end{array}$ \\
\hline \multirow[t]{10}{*}{$\begin{array}{l}\text { Safety organization } \\
\text { and management }\end{array}$} & $\begin{array}{l}\text { The Safety Management Division is a } \\
\text { professional part of my factory }\end{array}$ & 0.61 \\
\hline & $\begin{array}{l}\text { Employee safety is one of the priorities in this } \\
\text { factory }\end{array}$ & 0.64 \\
\hline & $\begin{array}{l}\text { Safety officers work with all parties to address } \\
\text { safety issues in the workplace }\end{array}$ & 0.67 \\
\hline & $\begin{array}{l}\text { The factory is open to accepting the opinions of } \\
\text { employees regarding safety issues in the factory }\end{array}$ & 0.65 \\
\hline & $\begin{array}{l}\text { My management states in writing their safety } \\
\text { policy }\end{array}$ & 0.18 (remove) \\
\hline & The factory has its safety inspection program & 0.59 \\
\hline & $\begin{array}{l}\text { The factory provides physical safety inspections } \\
\text { to employees on a scheduled basis }\end{array}$ & 0.54 \\
\hline & $\begin{array}{l}\text { Management always distributes workplace } \\
\text { safety regulations }\end{array}$ & 0.69 \\
\hline & $\begin{array}{l}\text { The factory provides appropriate safety } \\
\text { regulations }\end{array}$ & 0.58 \\
\hline & $\begin{array}{l}\text { The factory has procedures for managing } \\
\text { workplace safety }\end{array}$ & 0.53 \\
\hline \multirow{10}{*}{$\begin{array}{l}\text { Safety equipment } \\
\text { and measures }\end{array}$} & The pathway is always neat and orderly & 0.47 (remove) \\
\hline & $\begin{array}{l}\text { The machines are equipped with good } \\
\text { protective equipment }\end{array}$ & 0.79 \\
\hline & $\begin{array}{l}\text { Electrical equipment in the factory is well-taken } \\
\text { care }\end{array}$ & 0.79 \\
\hline & $\begin{array}{l}\text { The dangerous work environment is equipped } \\
\text { with good air circulation }\end{array}$ & 0.64 \\
\hline & $\begin{array}{l}\text { The factory provides Personal Protection } \\
\text { Equipment (PPE) to its employees }\end{array}$ & 0.80 \\
\hline & $\begin{array}{l}\text { The plant conducts measurements of hazardous } \\
\text { environments on a scheduled basis }\end{array}$ & 0.83 \\
\hline & The factory provides workplace safety labels & 0.85 \\
\hline & The factory conducts self-inspection & 0.85 \\
\hline & $\begin{array}{l}\text { The factory keeps records of regular safety } \\
\text { inspections }\end{array}$ & 0.81 \\
\hline & $\begin{array}{l}\text { The factory conducts personal safety } \\
\text { management of employees depending on the } \\
\text { results of their physical inspections }\end{array}$ & 0.80 \\
\hline \multirow[t]{2}{*}{$\begin{array}{l}\text { Safety } \\
\text { practices }\end{array}$} & $\begin{array}{l}\text { The factory provides safety training to all its } \\
\text { new employees }\end{array}$ & 0.90 \\
\hline & $\begin{array}{l}\text { The factory provides safety training to the } \\
\text { converted workers }\end{array}$ & 0.91 \\
\hline
\end{tabular}




\begin{tabular}{|c|c|c|}
\hline & $\begin{array}{l}\text { The factory provides safety training to the } \\
\text { person responsible for operating first aid }\end{array}$ & 0.89 \\
\hline & $\begin{array}{l}\text { The factory provides first aid training to its } \\
\text { employees }\end{array}$ & 0.89 \\
\hline & The factory safety trainer is a trained person & 0.86 \\
\hline \multirow[t]{5}{*}{$\begin{array}{l}\text { Safety training } \\
\text { evaluation }\end{array}$} & $\begin{array}{l}\text { Safety training is consistent with factory } \\
\text { training objectives }\end{array}$ & 0.86 \\
\hline & $\begin{array}{l}\text { At least } 3 \text { hours are allocated for safety training } \\
\text { in this factory }\end{array}$ & 0.87 \\
\hline & $\begin{array}{l}\text { The condition of the safety training place is very } \\
\text { comfortable }\end{array}$ & 0.91 \\
\hline & $\begin{array}{l}\text { Trainees need to undergo an achievement test } \\
\text { at the end of the safety training session }\end{array}$ & 0.93 \\
\hline & $\begin{array}{l}\text { The safety training objectives conducted are } \\
\text { not in line with the factory training objectives }\end{array}$ & 0.85 \\
\hline \multirow[t]{4}{*}{$\begin{array}{l}\text { Accident } \\
\text { investigation }\end{array}$} & $\begin{array}{l}\text { The factory regularly conducts accident } \\
\text { investigations }\end{array}$ & 0.90 \\
\hline & $\begin{array}{l}\text { The factory is seriously conducting accident } \\
\text { investigations }\end{array}$ & 0.91 \\
\hline & $\begin{array}{l}\text { The factory informs the results of the accident } \\
\text { investigation }\end{array}$ & 0.93 \\
\hline & $\begin{array}{l}\text { The factory uses information related to } \\
\text { accident investigations to improve workplace } \\
\text { safety }\end{array}$ & 0.88 \\
\hline \multirow[t]{5}{*}{ Accident statistic } & $\begin{array}{l}\text { You have never been injured at work in the last } \\
\text { year }\end{array}$ & 0.83 \\
\hline & $\begin{array}{l}\text { You have never had a disability at work in the } \\
\text { last year }\end{array}$ & 0.83 \\
\hline & $\begin{array}{l}\text { You will not experience any near-miss accident } \\
\text { in the next year }\end{array}$ & 0.92 \\
\hline & $\begin{array}{l}\text { You will not have any workplace injuries in the } \\
\text { next year }\end{array}$ & 0.90 \\
\hline & $\begin{array}{l}\text { You will not suffer death at work within the } \\
\text { next year }\end{array}$ & 0.88 \\
\hline
\end{tabular}

\section{Construct Reliability Analysis}

Based on previous studies involving PLS-SEM analysis, construct reliability measurements are usually tested through internal consistency methods (Straub et al., 2004). Internal consistency analysis was determined by Cronbach Alpha (CA) and Composite Reliability (CR) values (Hair et al., 2012). According to Hair et al (2011), CA and CR values must be equal to or greater than 0.70 to achieve internal consistency reliability. After analysis, the researcher found that the value of CA $(0.79-0.96)$ and the value of $C R(0.84-0.96)$ in this study exceeded the value of 0.70 as suggested by (Hair et al., 2011). Therefore, the researcher confirmed the existence of internal consistency in this study as in Table 4. 
Table 4: Composite Reliability (CR) and Cronbach Alpha (CA) values for internal consistency analysis

\begin{tabular}{|c|c|c|c|c|}
\hline No & Instrument & Dimension & $\begin{array}{l}\text { Composite } \\
\text { Reliability } \\
(\mathrm{CR}) \\
(>0.70)\end{array}$ & $\begin{array}{l}\text { Cronbach Alpha } \\
(\alpha) \\
\text { (CA) }(>0.70)\end{array}$ \\
\hline \multirow[t]{5}{*}{1} & \multirow[t]{5}{*}{ Safety climate } & $\begin{array}{l}\text { CEO safety commitment and } \\
\text { action }\end{array}$ & 0.95 & 0.95 \\
\hline & & Manager safety commitment & 0.95 & 0.95 \\
\hline & & $\begin{array}{l}\text { Employee safety } \\
\text { commitment }\end{array}$ & 0.96 & 0.96 \\
\hline & & Perceived risk & 0.95 & 0.95 \\
\hline & & Emergency response & 0.93 & 0.91 \\
\hline \multirow[t]{5}{*}{2} & \multirow{5}{*}{$\begin{array}{l}\text { Big five } \\
\text { personality }\end{array}$} & Openness to experience & 0.91 & 0.86 \\
\hline & & Conscientiousness & 0.89 & 0.84 \\
\hline & & Extrovertness & 0.88 & 0.83 \\
\hline & & Agreeableness & 0.87 & 0.81 \\
\hline & & Neurotics & 0.89 & 0.84 \\
\hline 3 & \multicolumn{2}{|c|}{ Safety performance } & 0.92 & 0.90 \\
\hline
\end{tabular}

\section{Convergent Validity Analysis}

Convergent validity refers to the extent to which a group of items represents a construct (Gefen \& Straub, 2005). In PLS analysis, convergent validity is measured through the value of Average Variance Extracted (AVE) (Urbach \& Ahlemann, 2010). Hair et al., (1998) suggested that the AVE value for each item in the construct must be $>0.50$. In this study, AVE values for safety climate $(0.65-0.74)$, personality $(0.64-0.71)$ and safety performance $(0.69)$. In this study, the AVE value is above 0.50 as in Table 5 . Based on the value of this AVE, this study proves the existence of the convergent validity of the instruments in this study.

Table 5: Average Variance Extracted (AVE) Values

\begin{tabular}{llll}
\hline No & Instrument & Dimension & $\begin{array}{l}\text { AVE } \\
(>\mathbf{0 . 5 0})\end{array}$ \\
\hline $\mathbf{1}$ & Safety climate & CEO safety commitment and action & 0.69 \\
\cline { 3 - 4 } & & Manager safety commitment & 0.69 \\
\cline { 3 - 4 } & & Employee safety commitment & 0.74 \\
\cline { 3 - 4 } & & Perceived risk & 0.72 \\
\cline { 3 - 4 } & & Emergency response & 0.65 \\
\hline $\mathbf{2}$ & \multirow{2}{*}{ Big Five personality } & Openness to experience & 0.71 \\
\cline { 3 - 4 } & & Conscientiousness & 0.68 \\
\cline { 3 - 4 } & & Extrovertness & 0.66 \\
\cline { 3 - 4 } & & Agreeableness & 0.64 \\
\cline { 3 - 4 } & & Neurotics & 0.67 \\
\hline $\mathbf{3}$ & Safety performance & & 0.69 \\
\hline
\end{tabular}




\section{Discrimination Validity Analysis}

Discriminatory validity refers to the extent to which each construct differs from the other construct. In PLS analysis, discriminant validity was measured using a cross-loading method (Henseler et al., 2015). The cross-loading method is made between the construct and the items in the model. The assessment made is that the cross-loading value of all items measured with the matched constructs should have a higher value than the matching values with other constructs (Grégoire \& Fisher, 2006; Hair et al., 2011; Henseler et al., 2015). In this study, the cross-loading value of each item matched to a particular construct was found to be higher than the unmatched construct as shown in Table 6. Thus, it proves the existence of discriminatory validity in this study.

Table 6: Output cross loading using SmartPLS

\begin{tabular}{|c|c|c|c|c|c|c|c|c|c|c|c|c|c|c|c|c|}
\hline ITE & IKP & IK & IK & IK & IK & $P$ & PC & $P E$ & PA & $P$ & PK & PK & PKA & PKP & PK & PK \\
\hline M & $U$ & $M$ & $P$ & $\mathrm{R}$ & $\begin{array}{l}M \\
B\end{array}$ & 0 & & & & $\mathrm{~N}$ & $P$ & $U$ & LK & LK & PK & SK \\
\hline IKPU & 0.8 & 0. & 0. & 0. & 0.5 & 0. & 0. & 0. & 0. & 0. & 0. & 0. & 0.6 & 0.5 & 0.5 & 0.3 \\
\hline 1 & 3 & 72 & 46 & 41 & 1 & 38 & 45 & 27 & 32 & 17 & 47 & 59 & 0 & 4 & 6 & 1 \\
\hline IKPU & 0.8 & 0. & 0. & 0. & 0.5 & 0. & 0. & 0. & 0. & 0. & 0. & 0. & 0.6 & 0.5 & 0.6 & 0.3 \\
\hline 2 & 3 & 77 & 47 & 33 & 0 & 44 & 41 & 31 & 36 & 22 & 53 & 61 & 2 & 8 & 0 & 1 \\
\hline IKPU & 0.7 & 0. & 0. & 0. & 0.5 & 0. & 0. & 0. & 0. & 0. & 0. & 0. & 0.4 & 0.4 & 0.5 & 0.2 \\
\hline 3 & 6 & 63 & 56 & 36 & 5 & 40 & 39 & 37 & 35 & 30 & 47 & 55 & 3 & 9 & 1 & 1 \\
\hline IKPU & 0.7 & 0. & 0. & 0. & 0.5 & 0. & 0. & 0. & 0. & 0. & 0. & 0. & 0.5 & 0.4 & 0.5 & 0.3 \\
\hline 4 & 9 & 65 & 57 & 36 & 1 & 31 & 43 & 21 & 28 & 21 & 42 & 57 & 0 & 7 & 1 & 4 \\
\hline IKPU & 0.7 & 0. & 0. & 0. & 0.4 & 0. & 0. & 0. & 0. & 0. & 0. & 0. & 0.5 & 0.5 & 0.5 & 0.2 \\
\hline 5 & 9 & 68 & 49 & 36 & 8 & 24 & 39 & 16 & 24 & 17 & 41 & 55 & 3 & 0 & 1 & 5 \\
\hline IKPU & 0.8 & 0. & 0. & 0. & 0.5 & 0. & 0. & 0. & 0. & 0. & 0. & 0. & 0.6 & 0.5 & 0.6 & 0.4 \\
\hline 6 & 2 & 73 & 48 & 39 & 4 & 36 & 43 & 32 & 45 & 23 & 51 & 61 & 0 & 7 & 1 & 0 \\
\hline IKPU & 0.8 & 0. & 0. & 0. & 0.5 & 0. & 0. & 0. & 0. & 0. & 0. & 0. & 6 & 0.5 & 0.5 & 0.2 \\
\hline 7 & 6 & 79 & 50 & 38 & 3 & 43 & 47 & 25 & 33 & 18 & 54 & 66 & 2 & 3 & 8 & 9 \\
\hline IKPU & 0.8 & 0. & 0. & 0. & 0.5 & 0. & 0. & 0. & 0. & 0. & 0. & 0. & 0 & 0.5 & 0.5 & 0.3 \\
\hline 8 & 9 & 78 & 52 & 37 & 0 & 38 & 45 & 22 & 37 & 22 & 5 & 65 & 9 & 7 & 7 & 4 \\
\hline IKPU & 0.8 & 0. & 0. & 0. & 0.5 & 0. & 0. & 0. & 0. & 0. & 0. & 0. & 0.6 & 0.6 & 0.5 & 0.3 \\
\hline 9 & 8 & 80 & 54 & 37 & 4 & 40 & 46 & 32 & 42 & 25 & 53 & 67 & 1 & 0 & 9 & 1 \\
\hline IKPU & 0.8 & 0. & 0. & 0. & 0.5 & 0. & 0. & 0. & 0. & 0. & 0. & 0. & 0.5 & 0.5 & 0.5 & 0.3 \\
\hline 10 & 5 & 77 & 54 & 38 & 2 & 42 & 50 & 28 & 42 & 22 & 53 & 62 & & 8 & 5 & 6 \\
\hline IKM & 0.7 & 0. & 0. & 0. & 0.4 & 0. & 0. & 0. & 0. & 0. & 0. & 0. & 0.6 & 0.5 & 0.5 & 0.2 \\
\hline 1 & 7 & 84 & 48 & 38 & 6 & 33 & 38 & 27 & 32 & 23 & 54 & 60 & & 0 & 0 & 6 \\
\hline IKM & 0.8 & 0. & 0. & 0. & 0.5 & 0. & 0. & 0. & 0. & 0. & 0. & 0. & 0.6 & 0.6 & 0.5 & 0.3 \\
\hline 2 & 1 & 89 & 58 & 39 & 6 & 35 & 46 & 28 & 32 & 24 & 54 & 67 & 1 & 0 & 5 & 5 \\
\hline IKM & 0.7 & 0. & 0. & 0. & 0.5 & 0. & 0. & 0. & 0. & 0. & 0. & 0. & 0.6 & 0.5 & 0.5 & 0.3 \\
\hline 3 & 2 & 83 & 52 & 33 & 1 & 30 & 35 & 25 & 30 & 27 & 50 & 66 & 1 & 5 & 7 & 5 \\
\hline IKM & 0.7 & 0. & 0. & 0. & 0.5 & 0. & 0. & 0. & 0. & 0. & 0. & 0. & 0.5 & 0.5 & 0.5 & 0.3 \\
\hline 4 & 4 & 80 & 61 & 36 & 6 & 34 & 45 & 27 & 33 & 26 & 41 & 65 & 7 & 0 & 6 & 7 \\
\hline IKM & 0.7 & 0. & 0. & 0. & 0.4 & 0. & 0. & 0. & 0. & 0. & 0. & 0. & 0.6 & 0.5 & 0.5 & 0.2 \\
\hline 5 & 5 & 82 & 42 & 38 & 8 & 35 & 40 & 30 & 36 & 20 & 48 & 62 & 0 & 6 & 6 & 9 \\
\hline IKM & 0.7 & 0. & 0. & 0. & 0.4 & 0. & 0. & 0. & 0. & 0. & 0. & 0. & 0.5 & 0.5 & 0.6 & 0.4 \\
\hline 6 & 0 & 83 & 42 & 32 & 3 & 38 & 37 & 33 & 42 & 22 & 53 & 6 & 7 & 9 & & 3 \\
\hline
\end{tabular}




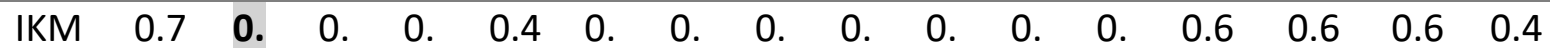
\begin{tabular}{lllllllllllllllll}
7 & 5 & 88 & 51 & 33 & 8 & 39 & 42 & 28 & 37 & 23 & 55 & 66 & 1 & 0 & 0 & 0 \\
\hline
\end{tabular}

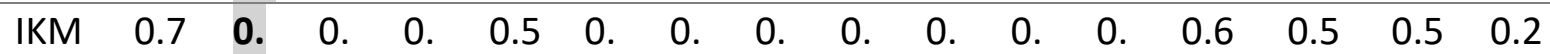
$\begin{array}{lllllllllllllllll}8 & 2 & 82 & 55 & 39 & 7 & 33 & 38 & 29 & 31 & 27 & 50 & 62 & 0 & 2 & 5 & 9\end{array}$

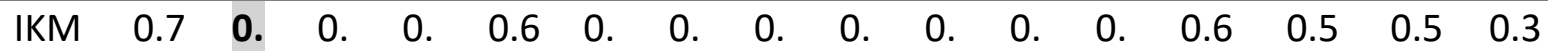
$\begin{array}{lllllllllllllllll}9 & 0 & 79 & 65 & 43 & 0 & 39 & 44 & 31 & 33 & 25 & 46 & 66 & 2 & 6 & 5 & 2 \\ \text { IKM } & 0.6 & 0 . & 0 . & 0 . & 0.5 & 0 . & 0 . & 0 . & 0 . & 0 . & 0 . & 0 . & 0.6 & 0.5 & 0.5 & 0.3\end{array}$ $\begin{array}{lllllllllllllllll}10 & 8 & 80 & 57 & 43 & 2 & 41 & 42 & 37 & 40 & 27 & 52 & 63 & 4 & 9 & 5 & 2\end{array}$

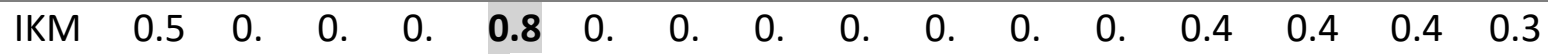
$\begin{array}{lllllllllllllllll}\text { B1 } & 5 & 55 & 52 & 40 & 0 & 31 & 36 & 31 & 39 & 24 & 31 & 56 & 8 & 4 & 4 & 0\end{array}$ $\begin{array}{lllllllllllllllll}\text { IKM } & 0.4 & 0 . & 0 . & 0 . & 0.8 & 0 . & 0 . & 0 . & 0 . & 0 . & 0 . & 0 . & 0.3 & 0.3 & 0.4 & 0.3\end{array}$ $\begin{array}{lllllllllllllllll}\text { B2 } & 6 & 42 & 49 & 30 & 3 & 24 & 27 & 32 & 27 & 13 & 28 & 52 & 9 & 6 & 2 & 2\end{array}$

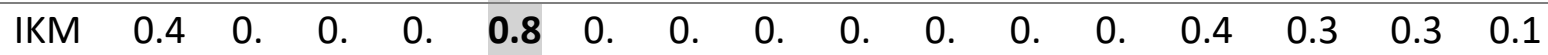
$\begin{array}{llllllllllllllllll}\text { B3 } & 8 & 47 & 58 & 32 & 0 & 29 & 34 & 31 & 26 & 16 & 26 & 50 & 1 & 3 & 6 & 8\end{array}$

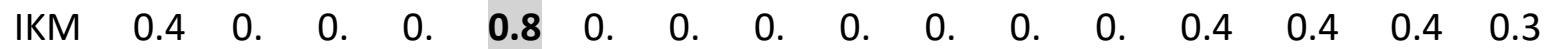
$\begin{array}{lllllllllllllllll}\text { B4 } & 9 & 49 & 50 & 28 & 2 & 21 & 34 & 36 & 31 & 17 & 31 & 51 & 6 & 0 & 4 & 0\end{array}$ $\begin{array}{lllllllllllllllll}\text { IKM } & 0.4 & 0 . & 0 . & 0 . & 0.7 & 0 . & 0 . & 0 . & 0 . & 0 . & 0 . & 0 . & 0.4 & 0.3 & 0.3 & 0.1\end{array}$ $\begin{array}{lllllllllllllllll}\text { B5 } & 8 & 48 & 49 & 31 & 1 & 19 & 32 & 24 & 19 & 16 & 27 & 49 & 3 & 7 & 3 & 8\end{array}$

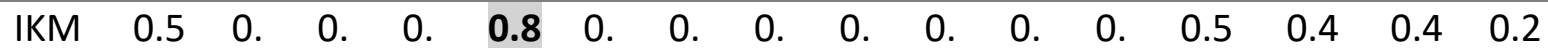
$\begin{array}{lllllllllllllllll}\text { B6 } & 5 & 58 & 53 & 41 & 3 & 35 & 39 & 40 & 36 & 23 & 37 & 54 & 4 & 6 & 1 & 7\end{array}$

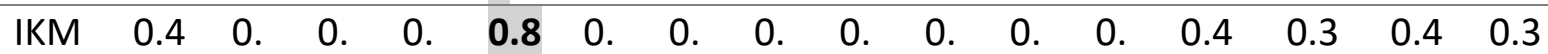
$\begin{array}{llllllllllllllll}\text { B7 } & 9 & 51 & 59 & 37 & 4 & 29 & 37 & 28 & 33 & 23 & 21 & 50 & 9 & 8 & 2\end{array}$

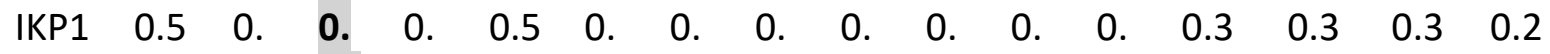
$\begin{array}{llllllllllllllll}1 & 54 & 86 & 38 & 3 & 32 & 45 & 32 & 31 & 19 & 32 & 48 & 9 & 7 & 5 & 6\end{array}$

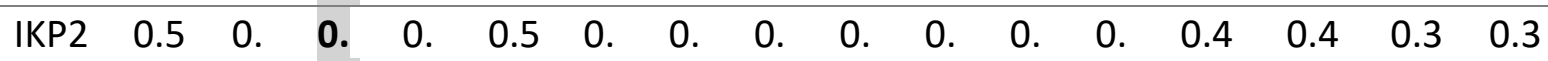
\begin{tabular}{llllllllllllllll}
6 & 59 & 89 & 41 & 4 & 32 & 45 & 32 & 36 & 20 & 34 & 51 & 4 & 0 & 9 & 2 \\
\hline
\end{tabular}

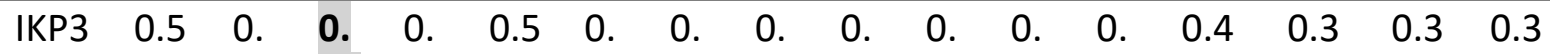
$\begin{array}{llllllllllllllll}4 & 57 & 88 & 42 & 2 & 27 & 44 & 20 & 32 & 11 & 31 & 51 & 3 & 3 & 7 & 4\end{array}$ $\begin{array}{lllllllllllllllll}\text { IKP4 } & 0.4 & 0 . & 0 . & 0 . & 0.5 & 0 . & 0 . & 0 . & 0 . & 0 . & 0 . & 0 . & 0.3 & 0.3 & 0.3 & 0.3\end{array}$ $\begin{array}{llllllllllllllll}3 & 46 & 82 & 41 & 1 & 27 & 42 & 27 & 36 & 16 & 23 & 44 & 7 & 2 & 5 & 3\end{array}$ $\begin{array}{lllllllllllllllll}\text { IKP5 } & 0.4 & 0 . & \mathbf{0 .} & 0 . & 0.5 & 0 . & 0 . & 0 . & 0 . & 0 . & 0 . & 0 . & 0.3 & 0.3 & 0.3 & 0.2\end{array}$ $\begin{array}{llllllllllllllll}8 & 49 & 86 & 37 & 8 & 31 & 42 & 40 & 33 & 16 & 33 & 49 & 8 & 5 & 7 & 5\end{array}$ $\begin{array}{lllllllllllllllll}\text { IKP6 } & 0.5 & 0 . & 0 . & 0 . & 0.5 & 0 . & 0 . & 0 . & 0 . & 0 . & 0 . & 0 . & 0.4 & 0.3 & 0.3 & 0.2\end{array}$ $\begin{array}{llllllllllllllll}0 & 53 & 79 & 40 & 6 & 33 & 46 & 33 & 36 & 19 & 32 & 52 & 6 & 9 & 4 & 5\end{array}$

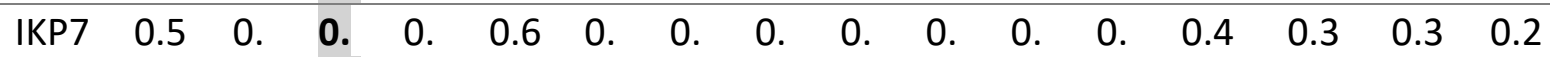
$\begin{array}{llllllllllllllll}6 & 56 & 83 & 44 & 1 & 29 & 49 & 37 & 40 & 21 & 37 & 53 & 7 & 9 & 6 & 6\end{array}$

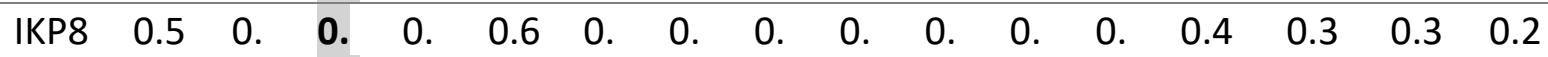
$\begin{array}{lllllllllllllllll} & 5 & 60 & 89 & 44 & 1 & 37 & 48 & 35 & 31 & 23 & 37 & 51 & 7 & 9 & 7 & 7 \\ \text { IKP9 } & 0.5 & 0 . & \mathbf{0 .} & 0 . & 0.5 & 0 . & 0 . & 0 . & 0 . & 0 . & 0 . & 0 . & 0.3 & 0.3 & 0.3 & 0.3\end{array}$ $\begin{array}{llllllllllllllll}5 & 54 & 87 & 42 & 8 & 32 & 47 & 30 & 34 & 17 & 32 & 5 & 9 & 4 & 5 & 0\end{array}$

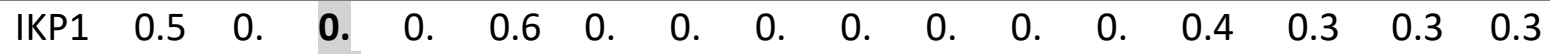
$\begin{array}{lllllllllllllllll}0 & 7 & 59 & 89 & 46 & 0 & 30 & 43 & 27 & 28 & 16 & 34 & 55 & 9 & 9 & 9 & 4\end{array}$

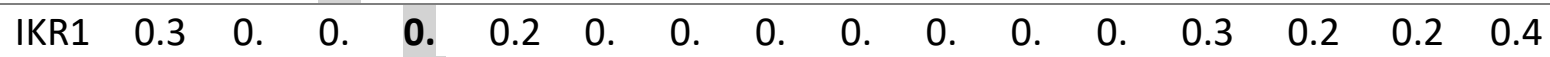
$\begin{array}{llllllllllllllll}4 & 34 & 38 & 82 & 9 & 27 & 39 & 20 & 22 & 21 & 28 & 34 & 2 & 8 & 5 & 3\end{array}$ $\begin{array}{lllllllllllllllll}\text { IKR2 } & 0.4 & 0 . & 0 . & 0 . & 0.3 & 0 . & 0 . & 0 . & 0 . & 0 . & 0 . & 0 . & 0.3 & 0.3 & 0.3 & 0.4\end{array}$ $\begin{array}{llllllllllllllll}2 & 44 & 46 & 89 & 6 & 24 & 39 & 20 & 26 & 27 & 34 & 40 & 7 & 3 & 1 & 5\end{array}$ 
$\begin{array}{lllllllllllllllll}\text { IKR3 } & 0.3 & 0 . & 0 . & 0 . & 0.3 & 0 . & 0 . & 0 . & 0 . & 0 . & 0 . & 0 . & 0.3 & 0.2 & 0.2 & 0.4\end{array}$ \begin{tabular}{llllllllllllllll}
6 & 37 & 43 & 88 & 3 & 21 & 37 & 21 & 32 & 23 & 27 & 35 & 2 & 9 & 5 & 2 \\
\hline
\end{tabular}

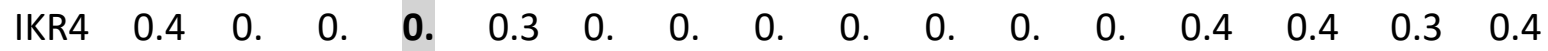
$\begin{array}{llllllllllllllll}0 & 43 & 41 & 84 & 6 & 33 & 34 & 19 & 31 & 23 & 34 & 41 & 3 & 1 & 4 & 1\end{array}$ $\begin{array}{lllllllllllllllll}\text { IKR5 } & 0.4 & 0 . & 0 . & 0 . & 0.4 & 0 . & 0 . & 0 . & 0 . & 0 . & 0 . & 0 . & 0.3 & 0.3 & 0.3 & 0.4\end{array}$ \begin{tabular}{llllllllllllllll}
1 & 41 & 44 & 90 & 0 & 28 & 34 & 25 & 26 & 27 & 31 & 34 & 6 & 5 & 3 & 3 \\
\hline
\end{tabular}

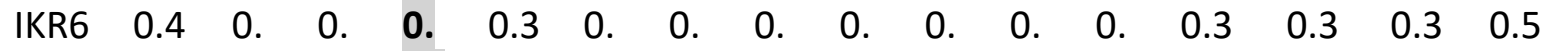
$\begin{array}{llllllllllllllll}1 & 38 & 48 & 89 & 8 & 21 & 35 & 17 & 21 & 22 & 27 & 33 & 4 & 2 & 1 & 0\end{array}$ $\begin{array}{lllllllllllllllll}\text { IKR7 } & 0.3 & 0 . & 0 . & 0 . & 0.3 & 0 . & 0 . & 0 . & 0 . & 0 . & 0 . & 0 . & 0.3 & 0.3 & 0.2 & 0.3\end{array}$ $\begin{array}{llllllllllllllll}8 & 36 & 39 & 82 & 8 & 22 & 28 & 18 & 17 & 22 & 26 & 33 & 5 & 5 & 7 & 9\end{array}$

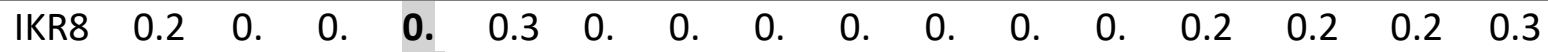
$\begin{array}{llllllllllllllll}6 & 25 & 33 & 72 & 6 & 16 & 31 & 12 & 17 & 23 & 18 & 26 & 9 & 9 & 5 & 9\end{array}$

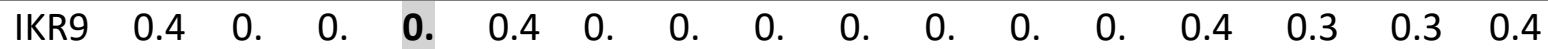
$\begin{array}{llllllllllllllll}0 & 42 & 35 & 84 & 0 & 27 & 34 & 16 & 19 & 31 & 22 & 34 & 3 & 7 & 3 & 3\end{array}$ $\begin{array}{lllllllllllllllll}\text { PA1 } & 0.4 & 0 . & 0 . & 0 . & 0.3 & 0 . & 0 . & 0 . & 0 . & 0 . & 0 . & 0 . & 0.3 & 0.2 & 0.3 & 0.2\end{array}$ $\begin{array}{llllllllllllllll}6 & 44 & 47 & 30 & 4 & 45 & 60 & 33 & 74 & 20 & 27 & 37 & 5 & 9 & 4 & 9\end{array}$ $\begin{array}{lllllllllllllllll}\text { PA2 } & 0.2 & 0 . & 0 . & 0 . & 0.2 & 0 . & 0 . & 0 . & 0 . & 0 . & 0 . & 0 . & 0.2 & 0.2 & 0.2 & 0.2\end{array}$ $\begin{array}{llllllllllllllll}7 & 27 & 20 & 17 & 6 & 35 & 38 & 51 & 81 & 25 & 20 & 19 & 1 & 3 & 5 & 4\end{array}$ $\begin{array}{lllllllllllllllll}\text { PA3 } & 0.3 & 0 . & 0 . & 0 . & 0.2 & 0 . & 0 . & 0 . & 0 . & 0 . & 0 . & 0 . & 0.1 & 0.2 & 0.2 & 0.2\end{array}$ $\begin{array}{llllllllllllllll}1 & 30 & 26 & 18 & 7 & 41 & 37 & 53 & 86 & 31 & 27 & 26 & 9 & 2 & 5 & 7\end{array}$ $\begin{array}{lllllllllllllllll}\text { PA4 } & 0.2 & 0 . & 0 . & 0 . & 0.3 & 0 . & 0 . & 0 . & 0 . & 0 . & 0 . & 0 . & 0.2 & 0.2 & 0.3 & 0.2\end{array}$ $\begin{array}{llllllllllllllll}7 & 27 & 26 & 20 & 1 & 39 & 34 & 61 & 76 & 36 & 21 & 21 & 1 & 5 & 2 & 3\end{array}$

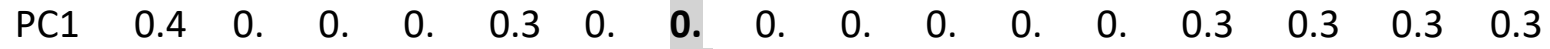
$\begin{array}{llllllllllllllll}4 & 41 & 43 & 30 & 8 & 54 & 82 & 39 & 44 & 18 & 25 & 36 & 5 & 4 & 7 & 3\end{array}$

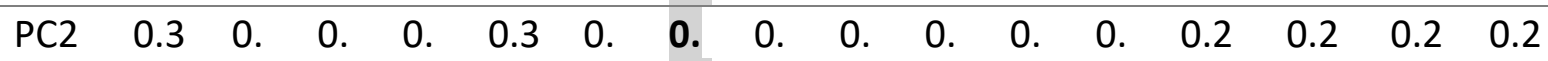
$\begin{array}{llllllllllllllll}9 & 38 & 3 & 39 & 3 & 44 & 78 & 45 & 47 & 23 & 18 & 31 & 7 & 7 & 2 & 1\end{array}$

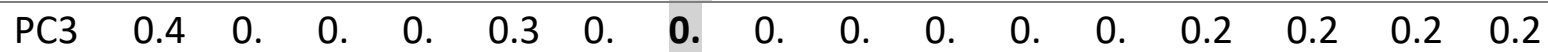
$\begin{array}{llllllllllllllll}3 & 38 & 41 & 30 & 2 & 47 & 85 & 36 & 46 & 14 & 24 & 30 & 5 & 0 & 7 & 3\end{array}$

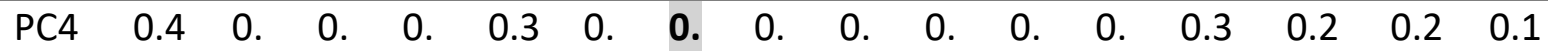
$\begin{array}{llllllllllllllll}69 & 44 & 49 & 36 & 7 & 52 & 83 & 41 & 44 & 15 & 22 & 37 & 2 & 4 & 4 & 7\end{array}$

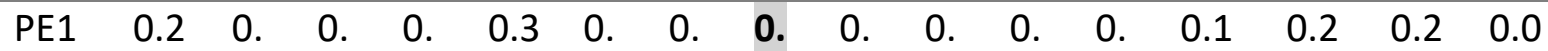
$\begin{array}{llllllllllllllll}8 & 31 & 32 & 16 & 5 & 41 & 42 & 82 & 44 & 14 & 29 & 28 & 6 & 7 & 4 & 9\end{array}$ $\begin{array}{lllllllllllllllll}\text { PE2 } & 0.1 & 0 . & 0 . & 0 . & 0.1 & 0 . & 0 . & 0 . & 0 . & 0 . & 0 . & 0 . & 0.0 & 0.2 & 0.1 & 0.1\end{array}$ $\begin{array}{llllllllllllllll}3 & 16 & 16 & 12 & 8 & 35 & 22 & 76 & 44 & 23 & 19 & 12 & 4 & 1 & 7 & 0\end{array}$ $\begin{array}{lllllllllllllllll}\text { PE3 } & 0.3 & 0 . & 0 . & 0 . & 0.4 & 0 . & 0 . & 0 . & 0 . & 0 . & 0 . & 0 . & 0.2 & 0.2 & 0.3 & 0.2\end{array}$ $\begin{array}{llllllllllllllll}8 & 38 & 38 & 26 & 0 & 42 & 47 & 83 & 51 & 15 & 26 & 33 & 7 & 9 & 0 & 8\end{array}$

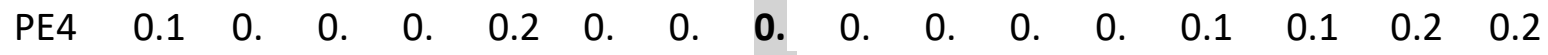
$\begin{array}{llllllllllllllll}9 & 23 & 27 & 14 & 9 & 35 & 40 & 84 & 59 & 18 & 14 & 18 & 3 & 8 & 3 & 5\end{array}$ $\begin{array}{lllllllllllllllll}\text { PKA } & 0.6 & 0 . & 0 . & 0 . & 0.5 & 0 . & 0 . & 0 . & 0 . & 0 . & 0 . & 0 . & 0.9 & 0.6 & 0.6 & 0.3\end{array}$ $\begin{array}{lllllllllllllllll}\text { LK1 } & 3 & 67 & 48 & 39 & 0 & 27 & 35 & 16 & 27 & 23 & 37 & 68 & 0 & 5 & 6 & 3\end{array}$ $\begin{array}{lllllllllllllllll}\text { PKA } & 0.6 & 0 . & 0 . & 0 . & 0.5 & 0 . & 0 . & 0 . & 0 . & 0 . & 0 . & 0 . & 0.9 & 0.7 & 0.7 & 0.3\end{array}$ $\begin{array}{lllllllllllllllll}\text { LK2 } & 2 & 67 & 46 & 39 & 0 & 30 & 35 & 19 & 30 & 22 & 41 & 69 & 1 & 4 & 04 & 6\end{array}$ \begin{tabular}{lllllllllllllllll}
\hline PKA & 0.6 & 0. & 0. & 0. & 0.5 & 0. & 0. & 0. & 0. & 0. & 0. & 0. & 0.8 & 0.7 & 0.6 & 0.3
\end{tabular} $\begin{array}{lllllllllllllllll}\text { LK3 } & 1 & 62 & 44 & 41 & 1 & 26 & 32 & 14 & 24 & 24 & 36 & 66 & 9 & 2 & 9 & 5\end{array}$ $\begin{array}{lllllllllllllllll}\text { PKA } & 0.6 & 0 . & 0 . & 0 . & 0.5 & 0 . & 0 . & 0 . & 0 . & 0 . & 0 . & 0 . & 0.8 & 0.7 & 0.7 & 0.4\end{array}$ $\begin{array}{lllllllllllllllll}\text { LK4 } & 0 & 65 & 39 & 35 & 2 & 27 & 30 & 23 & 30 & 20 & 42 & 67 & 9 & 4 & 0 & 5\end{array}$ 
$\begin{array}{lllllllllllllllll}\text { PKA } & 0.6 & 0 . & 0 . & 0 . & 0.5 & 0 . & 0 . & 0 . & 0 . & 0 . & 0 . & 0 . & 0.8 & 0.7 & 0.7 & 0.4\end{array}$ $\begin{array}{lllllllllllllllll}\text { LK5 } & 0 & 64 & 46 & 34 & 1 & 22 & 31 & 21 & 29 & 21 & 40 & 69 & 6 & 3 & 6 & 1\end{array}$ $\begin{array}{lllllllllllllllll}\text { PKP } & 0.2 & 0 . & 0 . & 0 . & 0.1 & 0 . & 0 . & 0 . & 0 . & 0 . & 0 . & 0 . & 0.1 & 0.1 & 0.0 & -\end{array}$ $\begin{array}{lllllllllllllllll}1 & 6 & 27 & 11 & 09 & 4 & 15 & 05 & 05 & 09 & 12 & 61 & 22 & 5 & 9 & 9 & 0.0\end{array}$

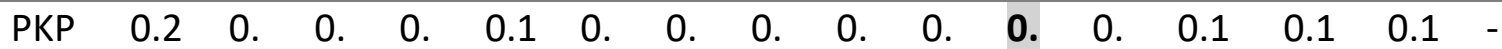
$\begin{array}{lllllllllllllllll}2 & 8 & 27 & 15 & 14 & 4 & 14 & 04 & 05 & 06 & 11 & 64 & 22 & 4 & 7 & 0 & 0.0\end{array}$ $\begin{array}{lllllllllllllllll}\text { PKP } & 0.3 & 0 . & 0 . & 0 . & 0.1 & 0 . & 0 . & 0 . & 0 . & 0 . & 0 . & 0 . & 0.2 & 0.3 & 0.2 & 0.0\end{array}$ $\begin{array}{lllllllllllllllll}3 & 5 & 38 & 19 & 16 & 7 & 21 & 15 & 12 & 14 & 15 & 67 & 35 & 4 & 2 & 4 & 7\end{array}$ $\begin{array}{lllllllllllllllll}\text { PKP } & 0.3 & 0 . & 0 . & 0 . & 0.2 & 0 . & 0 . & 0 . & 0 . & 0 . & 0 . & 0 . & 0.3 & 0 . & 0.3 & 0.2\end{array}$ $\begin{array}{lllllllllllllllll}4 & 9 & 44 & 19 & 22 & 5 & 23 & 18 & 22 & 30 & 26 & 65 & 37 & 0 & 37 & 5 & 3\end{array}$ $\begin{array}{lllllllllllllllll}\text { PKP } & 0.4 & 0 . & 0 . & 0 . & 0.3 & 0 . & 0 . & 0 . & 0 . & 0 . & 0 . & 0 . & 0.3 & 0.3 & 0.3 & 0.2\end{array}$ $\begin{array}{lllllllllllllllll}6 & 7 & 43 & 36 & 27 & 5 & 28 & 31 & 27 & 25 & 16 & 59 & 44 & 2 & 8 & 8 & 6\end{array}$ $\begin{array}{lllllllllllllllll}\text { PKP } & 0.3 & 0 . & 0 . & 0 . & 0.1 & 0 . & 0 . & 0 . & 0 . & 0 . & 0 . & 0 . & 0.2 & 0.2 & 0.2 & 0.2\end{array}$ $\begin{array}{lllllllllllllllll}7 & 3 & 36 & 23 & 25 & 6 & 31 & 22 & 25 & 28 & 09 & 54 & 3 & 6 & 5 & 3 & 1\end{array}$ $\begin{array}{lllllllllllllllll}\text { PKP } & 0.4 & 0 . & 0 . & 0 . & 0.2 & 0 . & 0 . & 0 . & 0 . & 0 . & 0 . & 0 . & 0.3 & 0.3 & 0.3 & 0.1\end{array}$ $\begin{array}{lllllllllllllllll}8 & 1 & 42 & 23 & 19 & 4 & 16 & 15 & 15 & 18 & 17 & 69 & 39 & 5 & 5 & 0 & 5\end{array}$ $\begin{array}{lllllllllllllllll}\text { PKP } & 0.3 & 0 . & 0 . & 0 . & 0.2 & 0 . & 0 . & 0 . & 0 . & 0 . & 0 . & 0 . & 0.2 & 0.2 & 0.2 & 0.1\end{array}$ $\begin{array}{lllllllllllllllll}9 & 5 & 36 & 29 & 21 & 1 & 17 & 18 & 22 & 12 & 11 & 58 & 37 & 7 & 9 & 6 & 1\end{array}$ $\begin{array}{lllllllllllllllll}\text { PKP } & 0.3 & 0 . & 0 . & 0 . & 0.2 & 0 . & 0 . & 0 . & 0 . & 0 . & 0 . & 0 . & 0.3 & 0.2 & 0.3 & 0.1\end{array}$ $\begin{array}{lllllllllllllllll}10 & 4 & 35 & 28 & 23 & 5 & 18 & 17 & 14 & 15 & 13 & 53 & 41 & 2 & 9 & 1 & 6\end{array}$ $\begin{array}{lllllllllllllllll}\text { PKP } & 0.6 & 0 . & 0 . & 0 . & 0.4 & 0 . & 0 . & 0 . & 0 . & 0 . & 0 . & 0 . & 0.7 & 0.7 & 0.9 & 0.4\end{array}$ $\begin{array}{lllllllllllllllll}\mathrm{K} 1 & 1 & 63 & 35 & 32 & 1 & 26 & 30 & 31 & 32 & 30 & 38 & 63 & 1 & 3 & 0 & 6\end{array}$ $\begin{array}{lllllllllllllllll}\text { PKP } & 0.6 & 0 . & 0 . & 0 . & 0.3 & 0 . & 0 . & 0 . & 0 . & 0 . & 0 . & 0 . & 0.7 & 0.7 & 0.9 & 0.4\end{array}$ $\begin{array}{lllllllllllllllll}\mathrm{K} 2 & 1 & 61 & 38 & 32 & 9 & 29 & 30 & 28 & 36 & 30 & 42 & 66 & 2 & 7 & 1 & 6\end{array}$ $\begin{array}{lllllllllllllllll}\text { PKP } & 0.6 & 0 . & 0 . & 0 . & 0.4 & 0 . & 0 . & 0 . & 0 . & 0 . & 0 . & 0 . & 0.7 & 0.7 & 0.9 & 0.4\end{array}$ \begin{tabular}{lllllllllllllllll}
$\mathrm{K} 3$ & 0 & 61 & 39 & 29 & 8 & 29 & 34 & 31 & 36 & 24 & 39 & 66 & 0 & 4 & 3 & 8 \\
\hline
\end{tabular} $\begin{array}{lllllllllllllllll}\text { PKP } & 0.6 & 0 . & 0 . & 0 . & 0.5 & 0 . & 0 . & 0 . & 0 . & 0 . & 0 . & 0 . & 0.7 & 0.6 & 0.8 & 0.5\end{array}$ $\begin{array}{lllllllllllllllll}\mathrm{K} 4 & 1 & 61 & 42 & 34 & 3 & 23 & 32 & 22 & 31 & 21 & 38 & 65 & 2 & 9 & 8 & 4\end{array}$ $\begin{array}{lllllllllllllllll}\text { PKP } & 0.6 & 0 . & 0 . & 0 . & 0.4 & 0 . & 0 . & 0 . & 0 . & 0 . & 0 . & 0 . & 0.7 & \mathbf{0 . 8} & 0.7 & 0.3\end{array}$ $\begin{array}{lllllllllllllllll}\text { LK1 } & 0 & 61 & 39 & 36 & 1 & 28 & 32 & 27 & 34 & 23 & 52 & 61 & 2 & 6 & 0 & 8\end{array}$ $\begin{array}{lllllllllllllllll}\text { PKP } & 0.4 & 0 . & 0 . & 0 . & 0.3 & 0 . & 0 . & 0 . & 0 . & 0 . & 0 . & 0 . & 0.6 & 0.8 & 0.6 & 0.3\end{array}$ $\begin{array}{lllllllllllllllll}\text { LK2 } & 9 & 5 & 30 & 32 & 7 & 26 & 19 & 29 & 24 & 25 & 41 & 52 & 1 & 7 & 5 & 7\end{array}$ $\begin{array}{lllllllllllllllll}\text { PKP } & 0.5 & 0 . & 0 . & 0 . & 0.4 & 0 . & 0 . & 0 . & 0 . & 0 . & 0 . & 0 . & 0.7 & 0.9 & 0.7 & 0.3\end{array}$ $\begin{array}{lllllllllllllllll}\text { LK3 } & 9 & 62 & 38 & 36 & 5 & 27 & 2 & 23 & 23 & 2 & 40 & 66 & 7 & 1 & 2 & 4\end{array}$ $\begin{array}{lllllllllllllllll}\text { PKP } & 0.6 & 0 . & 0 . & 0 . & 0.4 & 0 . & 0 . & 0 . & 0 . & 0 . & 0 . & 0 . & 0.7 & 0.9 & 0.7 & 0.4\end{array}$ $\begin{array}{lllllllllllllllll}\text { LK4 } & 3 & 65 & 44 & 39 & 7 & 29 & 33 & 27 & 31 & 27 & 42 & 67 & 4 & 3 & 5 & 1\end{array}$ $\begin{array}{lllllllllllllllll}\text { PKP } & 0.5 & 0 . & 0 . & 0 . & 0.4 & 0 . & 0 . & 0 . & 0 . & 0 . & 0 . & 0 . & 0.6 & 0.8 & 0.7 & 0.4\end{array}$ $\begin{array}{lllllllllllllllll}\text { LK5 } & 7 & 58 & 36 & 31 & 4 & 30 & 31 & 27 & 27 & 25 & 42 & 62 & 9 & 5 & 3 & 1\end{array}$ $\begin{array}{lllllllllllllllll}\text { PKS } & 0.4 & 0 . & 0 . & 0 . & 0.3 & 0 . & 0 . & 0 . & 0 . & 0 . & 0 . & 0 . & 0.4 & 0.4 & 0.5 & 0.8\end{array}$ $\begin{array}{lllllllllllllllll}\mathrm{K} 1 & 2 & 45 & 40 & 39 & 8 & 22 & 31 & 21 & 33 & 13 & 23 & 41 & 6 & 4 & 4 & 3\end{array}$ $\begin{array}{lllllllllllllllll}\text { PKS } & 0.4 & 0 . & 0 . & 0 . & 0.3 & 0 . & 0 . & 0 . & 0 . & 0 . & 0 . & 0 . & 0.4 & 0.3 & 0.5 & 0.8\end{array}$ $\begin{array}{lllllllllllllllll}\mathrm{K} 2 & 4 & 44 & 41 & 36 & 8 & 22 & 31 & 26 & 35 & 12 & 26 & 39 & 0 & 7 & 2 & 3\end{array}$ $\begin{array}{lllllllllllllllll}\text { PKS } & 0.2 & 0 . & 0 . & 0 . & 0.2 & 0 . & 0 . & 0 . & 0 . & 0 . & 0 . & 0 . & 0.3 & 0.3 & 0.4 & 0.9\end{array}$ $\begin{array}{lllllllllllllllll}\mathrm{K} 3 & 8 & 32 & 23 & 51 & 6 & 17 & 22 & 18 & 23 & 15 & 18 & 34 & 5 & 5 & 3 & 2\end{array}$ 


\begin{tabular}{|c|c|c|c|c|c|c|c|c|c|c|c|c|c|c|c|c|}
\hline PKS & 0.2 & 0. & 0. & 0. & 0.2 & 0. & 0. & 0. & 0. & 0. & 0. & 0. & 0.3 & 0.3 & 0.3 & 0.9 \\
\hline K4 & 8 & 32 & 21 & 48 & 2 & 17 & 21 & 15 & 25 & 18 & 22 & 34 & 3 & 4 & 9 & 0 \\
\hline PKS & 0.2 & 0. & 0. & 0. & 0.2 & 0. & 0. & 0. & 0. & 0. & 0. & 0. & 0.3 & 0.4 & 0.4 & 0.8 \\
\hline K5 & 3 & 26 & 24 & 48 & 4 & 12 & 23 & 22 & 28 & 18 & 13 & 32 & 2 & 0 & 5 & 8 \\
\hline PKU & 0.6 & 0. & 0. & 0. & 0.5 & 0. & 0. & 0. & 0. & 0. & 0. & 0. & 0.5 & 0.5 & 0.5 & 0.3 \\
\hline 2 & 1 & 64 & 51 & 38 & 3 & 26 & 32 & 21 & 26 & 14 & 47 & 78 & 6 & 3 & 2 & 8 \\
\hline PKU & 0.5 & 0. & 0. & 0. & 0.4 & 0. & 0. & 0. & 0. & 0. & 0. & 0. & 0.5 & 0.5 & 0.5 & 0.3 \\
\hline 3 & 8 & 64 & 51 & 3 & 9 & 34 & 36 & 23 & 20 & 13 & 53 & 79 & 4 & 7 & 5 & 3 \\
\hline PKU & 0.3 & 0. & 0. & 0. & 0.4 & 0. & 0. & 0. & 0. & 0. & 0. & 0. & 0.4 & 0.4 & 0.3 & 0.2 \\
\hline 4 & 9 & 39 & 34 & 24 & 2 & 10 & 19 & 13 & 16 & 10 & 46 & 64 & 4 & 7 & 8 & 8 \\
\hline PKU & 0.6 & 0. & 0. & 0. & 0.5 & 0. & 0. & 0. & 0. & 0. & 0. & 0. & 0.5 & 0.5 & 0.5 & 0.2 \\
\hline 5 & 0 & 61 & 49 & 35 & 6 & 28 & 36 & 35 & 36 & 23 & 51 & 80 & 9 & 5 & 5 & 9 \\
\hline PKU & 0.6 & 0. & 0. & 0. & 0.5 & 0. & 0. & 0. & 0. & 0. & 0. & 0. & 0.6 & 0.5 & 0.5 & 0.2 \\
\hline 6 & 2 & 62 & 52 & 31 & 8 & 28 & 35 & 31 & 33 & 20 & 47 & 83 & 1 & 5 & 7 & 9 \\
\hline PKU & 0.6 & 0. & 0. & 0. & 0.5 & 0. & 0. & 0. & 0. & 0. & 0. & 0. & 0.6 & 0.5 & 0.6 & 0.2 \\
\hline 7 & 3 & 64 & 57 & 37 & 8 & 31 & 38 & 24 & 28 & 20 & 41 & 85 & 1 & 3 & 0 & 8 \\
\hline PKU & 0.6 & 0. & 0. & 0. & 0.5 & 0. & 0. & 0. & 0. & 0. & 0. & 0. & 0.6 & 0.6 & 0.6 & 0.3 \\
\hline 8 & 2 & 66 & 46 & 31 & 5 & 35 & 32 & 28 & 29 & 14 & 46 & 85 & 9 & 1 & 5 & 8 \\
\hline PKU & 0.6 & 0. & 0. & 0. & 0.4 & 0. & 0. & 0. & 0. & 0. & 0. & 0. & 0.7 & 0.5 & 0.6 & 0.3 \\
\hline 9 & 0 & 66 & 38 & 35 & 3 & 25 & 32 & 23 & 24 & 13 & 42 & 81 & 2 & 8 & 4 & 3 \\
\hline PKU & 0.5 & 0. & 0. & 0. & 0.4 & 0. & 0. & 0. & 0. & 0. & 0. & 0. & 0.6 & 0.6 & 0.6 & 0.4 \\
\hline 10 & 8 & 61 & 40 & 31 & 6 & 24 & 32 & 18 & 28 & 13 & 38 & 80 & 9 & 3 & 7 & 2 \\
\hline \multirow[t]{2}{*}{ PN1 } & 0.2 & 0. & 0. & 0. & 0.1 & 0. & 0. & 0. & 0. & 0. & 0. & 0. & 0.2 & 0.2 & 0.2 & 0.1 \\
\hline & 5 & 28 & 17 & 27 & 4 & 33 & 27 & 19 & 40 & 78 & 14 & 17 & 0 & 0 & 0 & 9 \\
\hline \multirow[t]{2}{*}{ PN2 } & 0.2 & 0. & 0. & 0. & 0.2 & 0. & 0. & 0. & 0. & 0. & 0. & 0. & 0.2 & 0.2 & 0.2 & 0.1 \\
\hline & 4 & 24 & 21 & 28 & 4 & 27 & 20 & 20 & 26 & 81 & 26 & 21 & 0 & 5 & 7 & 0 \\
\hline \multirow[t]{2}{*}{ PN3 } & 0.1 & 0. & 0. & 0. & 0.2 & 0. & 0. & 0. & 0. & 0. & 0. & 0. & 0.2 & 0.2 & 0.2 & 0.1 \\
\hline & 6 & 19 & 13 & 19 & & 13 & 11 & 10 & 21 & 84 & 15 & 14 & 2 & 1 & 4 & 8 \\
\hline \multirow[t]{2}{*}{ PN4 } & 0.2 & 0. & 0. & 0. & 0.1 & 0. & 0. & 0. & 0. & 0. & 0. & 0. & 0.1 & 0.2 & 0.2 & 0.1 \\
\hline & 1 & 24 & 15 & 20 & 9 & 18 & 11 & 17 & 26 & 84 & 24 & 12 & 9 & 5 & 3 & 1 \\
\hline \multirow[t]{2}{*}{ PO1 } & 0.3 & 0. & 0. & 0. & 0.2 & 0. & 0. & 0. & 0. & 0. & 0. & 0. & 0.2 & 0.2 & 0.2 & 0.1 \\
\hline & 9 & 36 & 28 & 24 & 8 & 85 & 56 & 39 & 44 & 19 & 23 & 25 & 7 & 6 & 6 & 5 \\
\hline \multirow[t]{2}{*}{ PO2 } & 0.3 & 0. & 0. & 0. & 0.3 & 0. & 0. & 0. & 0. & 0. & 0. & 0. & 0.2 & 0.2 & 0.2 & 0.1 \\
\hline & 8 & 36 & 36 & 25 & 0 & 8 & 49 & 43 & 47 & 30 & 32 & 33 & 2 & 9 & 3 & 8 \\
\hline \multirow[t]{2}{*}{$\mathrm{PO} 3$} & 0.3 & 0. & 0. & 0. & 0.2 & 0. & 0. & 0. & 0. & 0. & 0. & 0. & 0.2 & 0.2 & 0.2 & 0.2 \\
\hline & 9 & 39 & 30 & 27 & 9 & 87 & 49 & 44 & 45 & 27 & 35 & 31 & 5 & 9 & 8 & 3 \\
\hline \multirow[t]{2}{*}{ PO4 } & 0.3 & 0. & 0. & 0. & 0.2 & 0. & 0. & 0. & 0. & 0. & 0. & 0. & 0.2 & 0.2 & 0.2 & 0.1 \\
\hline & 7 & 35 & 27 & 23 & 6 & 79 & 52 & 35 & 36 & 16 & 23 & 26 & 8 & 2 & 3 & 2 \\
\hline
\end{tabular}

Note: CEO safety commitment and action (IKPU), manager safety commitment (IKM), employee safety commitment (IKP), perceived risk (IKR), emergency response (IKMB), Openness to experience (PO), Conscientiousness (PC), Extrovertness (PE), Agreeableness (PA), Neurotics (PN), safety organization and management (PKP), safety equipment and measures (PKU), safety training practices (PKALK), safety training evaluation (PKPLK), accident investigation (PKPK) and accident statistics (PKSK) 


\section{Conclusions}

Confirmatory Factor Analysis (CFA) in the Structural Equation Modeling (SEM) Partial Least Square (PLS) analysis gives better results in testing the validity and reliability of an instrument. The test results can be indicated by construct validity, convergent validity, construct reliability, and discriminant validity.

\section{Acknowledgement}

The author(s) received no financial support for the research, authorship, and/or publication of this article.

\section{References}

Baldasaro, R. E., Shanahan, M. J., \& Bauer, D. J. (2013). Psychometric properties of the miniIPIP in a large, nationally representative sample of young adults. Journal of Personality Assessment, 95(1), 74-84. https://doi.org/10.1080/00223891.2012.700466

Donnellan, M. B., Oswald, F. L., Baird, B. M., \& Lucas, R. E. (2006). The Mini-IPIP scales: Tinyyet effective measures of the Big Five factors of personality. Psychological Assessment, 18(2), 192-203. https://doi.org/10.1037/1040-3590.18.2.192

Gefen, D., \& Straub, D. (2005). A Practical Guide To Factorial Validity Using PLS-Graph: Tutorial And Annotated Example. Communications of the Association for Information Systems, 16, 91 109. https://doi.org/10.17705/1cais.01605

Goldberg, L. R. (1999). A Broad-Bandwidth, Public Domain, Personality Inventory Measuring the Lower-Level Facets of Several Five-Factor Models. In I. Mervielde, I. Deary, F. De Fruyt, \& F. Ostendorf (Eds.), Personality Psychology in Europe (Vol. 7). Tilburg, The Netherlands: Tilburg University Press (pp. 7-28).

Greeno, E. J., Hughes, A. K., Hayward, R. A., \& Parker, K. L. (2007). A Confirmatory Factor Analysis of the Professional Opinion Scale. Research on Social Work Practice, 17(4), 482-493. https://doi.org/10.1177/1049731506299024

Grégoire, Y., \& Fisher, R. J. (2006). The effects of relationship quality on customer retaliation. Marketing Letters, 17(1), 31-46. https://doi.org/10.1007/s11002-006-3796-4

Hair, J. F., Black, W., Babin, B., \& Anderson, R. (1998). Multivariate Data Analysis. A Global Perspective. In MacMillan Publishing Company, New York, NY (Seventh Ed). https://doi.org/10.2307/1266874

Hair, J. F., Ringle, C. M., \& Sarstedt, M. (2011). PLS-SEM: Indeed a silver bullet. Journal of Marketing Theory and Practice, 19(2), 139-152. https://doi.org/10.2753/MTP10696679190202

Hair, J. F., Sarstedt, M., Pieper, T. M., \& Ringle, C. M. (2012). The Use of Partial Least Squares Structural Equation Modeling in Strategic Management Research: A Review of Past Practices and Recommendations for Future Applications. Long Range Planning, 45(5-6), 320 340. https://doi.org/10.1016/j.Irp.2012.09.008

Henseler, J., Ringle, C. M., \& Sarstedt, M. (2015). A new criterion for assessing discriminant validity in variance-based structural equation modeling. Journal of the Academy of Marketing Science, 43(1), 115-135. https://doi.org/10.1007/s11747-014-0403-8

Kline, R. B. (2015). Principles and practice of structural equation modeling. In Methodology in the Social Sciences (4 edition, pp. 1-554).

Straub, D., Boudreau, M., \& Gefen, D. (2004). Validation Guidelines for IS Positivist Research. Communications of the Association for Information Systems, 13(24), 380-427. 
https://doi.org/10.17705/1cais.01324

Urbach, N., \& Ahlemann, F. (2010). Model selection in information systems research using partial least squares based structural equation modeling. International Conference on Information Systems, ICIS 2012, 11(2), 5-40.

Wu, T.-C., Chen, C.-H., \& Li, C.-C. (2008). A Correlation Among Safety Leadership, Safety Climate, and Safety Performance. Journal of Loss Prevention in the Process Industries, 21(3), 307-318. https://doi.org/10.1016/j.jlp.2007.11.001

Wu, T.-C., Liu, C.-W., \& Lu, M.-C. (2007). Safety Climate in University and College Laboratories: Impact of Organizational and Individual Factors. Journal of Safety Research, 38, 91-102. https://doi.org/10.1016/j.jsr.2007.01.003 